\title{
A Study on the Performace of Equity Mutual Funds (With special reference to equity large cap and mid cap mutual funds)
}

\author{
R.Nandhini, M.com, M.Phil \& Dr.V.Rathnamani, M.B.A, M.Com, M.Phil, Ph.d, SET., \\ Assistant professor National college (autonomous) Trichy-620001
}

\begin{abstract}
Mutual fund is an instrument of investing funds. A number of mutual fund schemes are available for investors to gain. India is one of the largest and most important emerging market nations, and since 2010, Indian benchmark indices have shown a strong uptrend. The importance of mutual funds in stock market has grown dramatically in last decades. The majority of market analysts expect this upward momentum to continue over the long term. Indian-focused equity mutual funds offer investors opportunities for substantial capital gains. Equities have out-performed other investment asset classes over the long-term in India as well as globally. Therefore, investors seeking the higher potential growth rates available in major emerging market areas may consider globally diversifying their overall investment portfolio with mutual funds that hold Indian equities. The present study focused on the performance of select equity large and small cap mutual funds and it was analyzed with risk return measurement tools such as alpha, beta, standard deviation and Sharpe ratio.
\end{abstract}

Keywords: mutual fund, higher return, capital gains.

\section{Introduction}

A Mutual Fund is an ideal investment vehicle where number of investors pools their money with common investment goal. Each mutual fund with different type of schemes is managed by respective AMC. An investor can invest his money in one or more schemes of mutual fund according to his choice and becomes the unit holder of the scheme. The invested money in a particular scheme of mutual fund is then invested by a fund manager in different types of suitable stock, bonds and money market instruments. Each mutual fund is managed by qualified professional man, who uses this money to create a portfolio. The mutual fund will diversify the portfolio over a variety of investment vehicles. Mutual funds play a vital role in resource mobilization and its efficient allocation to the productive resources of the economic system throughout the world; these funds have worked as reliable instruments of change in financial intermediation, development of capital growth and growth of corporate sector.

\section{Significance of the Study:}

The recent trends in the stock market have shown that average retail investors always lost with periodic bearish trends. Emergence of mutual funds in the Indian scenario is a product of constraints on the banking sector to tap the fruits of capital market and reluctance of the investors to direct plunge in complex and erratic financial market operations. Since, household sector share in much larger in country's savings. It is utmost essential for the government and mutual fund manager to guide their deployment of savings in the right direction. Thus with a plethora of mutual funds schemes available for option and their impressive growth in India, there is a need for the present study to light the performance of mutual funds, further it could guide the retail and small investors to make appropriate decisions while selecting the investment avenues for their hard earned savings through mutual fund vehicle. Performance evaluation would help investors to choose the best schemes available in the market.

\section{Review of Literature}

Literature on mutual funds performance evaluation is enormous. In this section, a few research studies that have influenced the preparation of this paper are discussed.

Rao Narayan and Ravindram Examined the performance evaluation of Indian mutual fund industry in a bear market was carried out through relative performance index, risk-return analysis, Treynor's ratio, Sharpe's ratio, Jensen's ratio and Fama's measure. The data was monthly closing NAV's collected from AMFI for the period of Sep. 98 to April 02 (bear period) of 269 open ended scheme. They excluding the funds whose return were less than risk free returns, 58 schemes were used for further analysis. The result of relative measures suggested that most of the mutual fund schemes in the sample of 58 were able to satisfy investor's expectation by giving excess returns over expected returns based on both premiums for systematic risk and total risk.

Noulas and Athanasios Evaluated the performance of Greek equity funds during the period 19972000. The evaluation was based on the analysis of risk and return. The first three years were characterized by positive returns of the stock market and the fourth year was year of rapid fall of the stock market with respect to 
risk and return. The result showed that there were big differences among the equity mutual funds with respect to risk and return and the result indicated that there was a positive relation between risk and return for the whole period while the betas for all funds were smaller than one.

Deb et al. Evaluated return based analysis of equity mutual funds in India using quadratic optimization of an asset class factor model proposed by William Sharpe. The data used in the study covers the period from January 2000 to January 2005. They found the styles benchmarks of each sample of equity funds as optimum exposure to eleven passive asset class indexes. They also analyzed the relative performance of the funds with respect to their style benchmarks. The result of the study showed that the funds have not been able to beat their style benchmarks on the average.

Somya used some additional, measures like information ratio, appraisal ratio and M2 measure other than conventional performance measures to bring out additional information about the competence of the fund manager. He was observed that study period from Jan2000 to Dec 2005 could broadly divided into two phases, the first being a bear period while the second one being a predominantly bull period. He found that, during the out of sample period, which is an outright bull period, the funds have outperformed well on the average but their benchmarks have performed even better.

Panwar and Madhumathi used sample of public sector and private sector funds of varied net asset to investigate the differences in characteristics of asset held, portfolio diversification on investment performance for the period May, 2002 to May, 2005. The study found that public sector sponsored funds do not differ significantly from public sector sponsored funds in terms of mean returns percentage. The study was also found that there was a statistical difference between sponsorship classes in terms ESDAR (excess standard deviation adjusted returns) as a performance measure,

Prince and Bacon in their research paper analyzed the small cap growth stock sector of mutual fund industry against risk-free and market returns over the ten years 1997-2006. In this paper result were tested against a toolkit of performance of benchmarks to see if expected performance closely corresponds to actual results. The results indicated that some excess returns have been generated however beyond a handful of the funds, it is impossible to rely upon a single benchmark as a reliable indicator of even past performance. The evidence tends to support market efficiency since for the most part, the actively managed funds examined in this study produced returns that were largely expected.

Gohar et al. compared the performance of different types of mutual funds in Pakistan and concluded that equity funds outperform income funds. Sample has been selected on the ranking of companies as per Pakistan Credit Rating Agency (PACRA) and the data will be collected for five years from 2005 to 2009 on monthly basis. The finding showed that within equity funds, broker backed category shows better performance than institutional funds and institutional funds are outperforming broker backed funds among income funds.

Dhanda made an attempt to study the performance evaluation of selected open ended schemes in terms of risk and return relationship by using rate of return, Beta, Standard Deviation, Sharp Ratio and Treynor Ratio. BSE-30 has been used as a benchmark to study the performance of mutual fund in India and the study period has been taken from April 1, 2009 to March 31, 2011. The finding of the study revealed that only three scheme have performed better than benchmark. Kumar Lenin Nooney and Devi Rama

Vengapandu evaluated the performance of selected mutual funds using average rate of return, standard deviation, Risk/Return, Sharpe ratio, Treynor ratio, Jenson Ratio and tested the hypothesis with ANOVA analysis. The sample for the study consists of 340 mutual funds belonging to Money market, Debt, Equity and Balanced category funds and further classified into public and private funds. The analysis of the study showed that there is no significant difference between the returns of private and public mutual funds.

\section{Objectives:}

1) To analyse the performance of a selected Equity Large cap mutual fund schemes.

2) To analyse the performance of a selected Equity Small \& Mid mutual fund schemes.

3) To study the measures of risk\& return associated with selected mutual fund.

4) To know whether the mutual funds are able to provide reward to variability and volatility.

\section{Sample Selection:}

\section{Research Methodology}

The researcher has chosen the available equity large and small\& mid cap mutual fund schemes. Mutual fund scheme for the purpose of the study have been selected in terms of CRISIL rating and risk grade.

\begin{tabular}{|l|l|l|}
\hline S.NO & TYPE OF THE FUND & NATURE OF THE FUND \\
\hline 1 & Large cap & $\begin{array}{l}\text { Equity mutual funds that invest more than 75\% in CRISIL - defined large cap } \\
\text { stocks for a minimum of four out of six months in each period over the last 2 years. }\end{array}$ \\
\hline 2 & Small \& Mid cap & $\begin{array}{l}\text { Equity mutual funds that invest less than 45\% in CRISIL - defined large cap stocks } \\
\text { for a minimum of four out of six months in each period over the last 2 years. }\end{array}$ \\
\hline
\end{tabular}




\section{Data Collection}

The present study is based on secondary data which is collected from various sources like published annual reports of the sponsoring agencies, online bulletins, journals books, magazines, brochures, newspapers and other published and online material.

Time Period of the Study:

A period of 5 years from April $1^{\text {st }} 2012$ to March $31^{\text {st }} 2016$ have been taken up for the purpose of the study.

\section{Statistical Tools:}

The present study made an attempt to analyze the performance of the selected mutual fund schemes with the market during the study period of 5 years. In order to achieve the objectives an analysis has been made to compare these schemes with the market on the basis of risk and return. Different relevant and advanced statistical tools have been employed for analyzing the performance of selected mutual funds.

\section{Standard Deviation (SD)}

The measure of SD indicates the volatility. SD evaluates the volatility of the fund. The standard deviation of a fund measures the risk by measuring the degree to which the fund fluctuates in relation to its average return of a fund over a period of time. In other words, it is a measure of the consistency of a mutual fund's returns. A higher SD number indicates that the net asset value (NAV) of the mutual fund is more volatile and, it is riskier than a fund with a lower SD.

\section{BETA}

Beta is a measure of the volatility of a particular fund in comparison to the market as a whole, that is, the extent to which the fund's return is impacted by market factors Beta value which is below 1.0 indicate the fund is low risk category, the value which is more than 1.0 indicate the fund is in high risk category

\section{ALPHA}

The measure of alpha shows the price risk apart from the performance of fund. A positive alpha means the fund has outperformed with its benchmark index, where a negative alpha indicates that a fund had underperformed with its Benchmark index. The positive alpha is the healthier for investors.

\section{R-SQUARED}

The correlation between bench mark return and portfolio return is given by R- squared. R-squared measures the relationship between a portfolio and its benchmark. It is simply a measure of the correlation of the portfolio's returns to the benchmark's returns. R-squared can be used to ascertain the significance of a particular beta or alpha. Generally, a higher R-squared will indicate a more useful beta figure. If the R-squared is lower, then the beta is less relevant to the fund's performance.

\section{Sharpe Ratio}

Sharpe ratios are used for risk adjusted measure for a fund. Sharpe ratio (SR) is another important measure that evaluates the return that a fund has generated relative to the risk taken. Risk here is measured by SD. It is used for funds that have low correlation with benchmark index. This ratio helps an investor to know whether it is a safe to invest in this fund by taking the quantum of risk. . In other words, a mutual fund with a higher SR is better because it implies that it has generated higher returns for every unit of risk that was taken. On the contrary, a negative Sharpe ratio indicates that a risk-free asset would have performed better than the fund being analyzed

TABLE .1 NAVS OF LARGE CAP FUNDS

\begin{tabular}{|l|l|l|l|l|l|}
\hline YEAR & 2012 & 2013 & 20114 & 2015 & 2016 \\
\hline FUND NAME & \multicolumn{2}{|c|}{ NAV IN RUPEES } & \multicolumn{4}{|l|}{$\mid$} \\
\hline SBI BLUE CHIP GROWTH & 16.56 & 17.82 & 26.34 & 28.45 & 29.57 \\
\hline KOTAK SELECT FOCUS REGULAR FUND & 13.24 & 14.06 & 22.19 & 22.85 & 24.46 \\
\hline BIRLA SUNLIFE TOP 200 FUND & 25.96 & 28.33 & 42.19 & 42.17 & 44.30 \\
\hline BNP PARIBAS EQUITY FUND & 39.49 & 42.91 & 63.25 & 66.78 & 63.61 \\
\hline FRANKLIN INDIA BLUE CHIP FUND & $\mathbf{2 3 6 . 6 7}$ & $\mathbf{2 4 6 . 3 2}$ & $\mathbf{3 3 8 . 0 0}$ & $\mathbf{3 4 4 . 8 2}$ & $\mathbf{3 6 3 . 6 4}$ \\
\hline
\end{tabular}

\section{Source: Secondary data.}

The table 1 shows the net asset value (NAV) of selected equity large cap schemes for 5 years. There was an increase in NAV during the study period of all five funds. It is mainly due to the upward movement in the stock market and there was a strong improvement in quantity as well as quality of product and service offerings in recent years. 
A Study on the Performace of Equity Mutual Funds (With special reference to equity large cap and ..

TABLE. 2 RETURNS FOR LARGE CAP MUTUAL FUNDS

\begin{tabular}{|c|c|c|c|c|c|c|c|}
\hline YEAR & 2012 & 2013 & 2014 & 2015 & 2016 & \multirow[t]{2}{*}{ AVG } & \multirow[t]{2}{*}{ RANK } \\
\hline FUND NAME & \multicolumn{5}{|c|}{ RETURN IN PERCENTAGE } & & \\
\hline SBI BLUE CHIP FUND & 38.23 & 7.58 & 47.86 & 7.99 & 3.94 & $21.12 \%$ & 2 \\
\hline KOTAK SELECT FOCUS REGULAR FUND & 33.45 & 6.13 & 57.87 & 2.96 & 7.86 & $21.65 \%$ & $\mathbf{1}$ \\
\hline BIRLA SUNLIFE TOP 200 FUND & 36.36 & 9.15 & 48.19 & $(\mathbf{0 . 0 5})$ & 5.03 & $19.7 \%$ & 3 \\
\hline BNP PARIBAS EQUITY FUND & 30.50 & 8.66 & 47.40 & 5.58 & (4.75) & $17.36 \%$ & 4 \\
\hline FRANKLIN INDIA BLUE CHIP FUND & 26.79 & 4.08 & 37.22 & 2.02 & 5.46 & $15.11 \%$ & 5 \\
\hline
\end{tabular}

Source: Secondary data.

Table 2 reveals the return earned by different large cap funds offered by different Mutual Fund companies during the study period (2012-2016). The average return of KOTAK SELECT FOCUS REGULAR (G) is 21.65percent. The average returns of other funds such as SBI BLUE CHIP (G), BIRLA SUNLIFE TOP $200(\mathrm{G})$, BNP PARIBAS EQUITY (G) and FRANKLIN INDIA BLUE CHIP (G) are 21.12 percent, 19.7 percent, 17.36 percent and 15.11 percent respectively. The return earned by different funds has been ranked. It is observed that the return from KOTAK SELECT FOCUS REGULAR is the highest followed by SBI BLUE CHIP, BIRLA SUNLIFE TOP 200, BNP PARIBAS EQUITY (G) and FRANKLIN INDIA BLUE CHIP fund. BNP PARIBAS EQUITY and BIRLA SUNLIFE TOP 200 fund show negative return during the year 2015 and 2016 due to economic slowdown, volatility in the share market and poor monsoon conditions.

TABLE .3 STATSTICAL TOOLS USED FOR EVALUATION OF LARGE CAP MUTUAL FUNDS

\begin{tabular}{|l|l|l|l|l|l|}
\hline FUND NAME & $\begin{array}{l}\text { Standard } \\
\text { Deviation }\end{array}$ & Beta & Alpha & R.Squared & Sharpe ratio \\
\hline SBI BLUE CHIP FUND & $12.073 \%$ & $\mathbf{0 . 8 8}$ & $10.81 \%$ & $\mathbf{0 . 9 3}$ & 1.31 \\
\hline KOTAK SELECT FOCUS REGULAR FUND & $15.11 \%$ & 1.03 & $11.66 \%$ & $\mathbf{0 . 9 0}$ & $\mathbf{1 . 2 3}$ \\
\hline BIRLA SUNLIFE TOP 200 FUND & $14.77 \%$ & 1.02 & $7.96 \%$ & $\mathbf{0 . 9 2}$ & $\mathbf{1 . 0 0}$ \\
\hline BNP PARIBAS EQUITY FUND & $15.65 \%$ & 1.02 & $\mathbf{6 . 3 7 \%}$ & $\mathbf{0 . 8 3}$ & $\mathbf{0 . 8 4}$ \\
\hline FRANKLIN INDIA BLUE CHIP FUND & $13.75 \%$ & $\mathbf{0 . 9 6}$ & $\mathbf{5 . 2 5 \%}$ & $\mathbf{0 . 9 4}$ & $\mathbf{0 . 8 5}$ \\
\hline
\end{tabular}

Source: Secondary data.

Table. 3 reveals the statistical evaluation of large cap mutual funds. The volatility impact is less for SBI BLUE $\mathrm{CHIP}$ as its standard deviation is less. The performance of the fund is excellent as revealed by beta, alpha, Rsquared and Sharpe ratio. Of these funds considered for the study SBI BLUE CHIP fund has performed well.

TABLE .4 NAVs OF SMALL\&MID CAP MUTUAL FUNDS

\begin{tabular}{|l|l|l|l|l|l|}
\hline YEAR & 2012 & 2013 & 20114 & 2015 & 2016 \\
\hline FUND NAME & \multicolumn{2}{|c|}{ NAV IN RUPEES } & & \multicolumn{1}{|c|}{} \\
\hline FRAKLIN INDIA SMALLER COMPANIES FUND & 17.07 & $\mathbf{1 9 . 3 2}$ & $\mathbf{3 6 . 7 0}$ & $\mathbf{4 0 . 2 0}$ & $\mathbf{4 3 . 6 1}$ \\
\hline MIRAE ASSET EMERGING BLUE CHIP FUND & $\mathbf{1 3 . 9 0}$ & $\mathbf{1 5 . 1 0}$ & $\mathbf{2 7 . 8 7}$ & $\mathbf{3 1 . 8 0}$ & $\mathbf{3 5 . 2 2}$ \\
\hline RELIANCE SMALLER CAP FUND & $\mathbf{1 0 . 9 0}$ & $\mathbf{1 2 . 1 9}$ & $\mathbf{2 4 . 0 9}$ & $\mathbf{2 7 . 7 3}$ & $\mathbf{2 7 . 8 4}$ \\
\hline SBI MAGNUM MID CAP FUND & $\mathbf{2 7 . 5 1}$ & $\mathbf{3 1 . 2 4}$ & $\mathbf{5 3 . 7 2}$ & $\mathbf{6 1 . 7 4}$ & $\mathbf{6 5 . 0 1}$ \\
\hline FRANKLIN INDIA PRIMA FUND & $\mathbf{3 3 0 . 5 3}$ & $\mathbf{3 5 5 . 0 0}$ & $\mathbf{6 3 2 . 4 1}$ & $\mathbf{6 7 5 . 4 8}$ & $\mathbf{7 2 4 . 7 6}$ \\
\hline
\end{tabular}

Source: Secondary data

The table. 4 shows the net asset value (NAV) of selected equity small and mid cap schemes for 5 years. There was an increase in NAV during the study period of all five funds. It is mainly due to the upward movement in the stock market and there was a strong improvement in quantity as well as quality of product and service offerings in recent years.

TABLE .5 RETURNS FOR SMALL\&MID CAP MUTUAL FUNDS

\begin{tabular}{|l|l|l|l|l|l|l|l|}
\hline YEAR & 2012 & 2013 & 2014 & 2015 & 2016 & AVG & RANK \\
\hline FUND NAME & \multicolumn{5}{|c|}{ RETURN IN PERCENTAGE } \\
\hline FRAKLIN INDIA SMALLER COMPANIES FUND & $\mathbf{5 1 . 7 0}$ & $\mathbf{1 3 . 2 2}$ & $\mathbf{8 9 . 9 2}$ & $\mathbf{9 . 5 6}$ & $\mathbf{8 . 4 7}$ & $\mathbf{3 4 . 5 7 \%}$ & $\mathbf{1}$ \\
\hline MIRAE ASSET EMERGING BLUE CHIP FUND & $\mathbf{4 5 . 5 6}$ & $\mathbf{8 . 6 1}$ & $\mathbf{8 4 . 6 2}$ & $\mathbf{1 4 . 0 8}$ & $\mathbf{1 0 . 7 7}$ & $\mathbf{3 2 . 7 2} \%$ & $\mathbf{3}$ \\
\hline RELIANCE SMALLER CAP FUND & $\mathbf{4 1 . 8 9}$ & $\mathbf{1 1 . 8 9}$ & $\mathbf{9 7 . 6 0}$ & $\mathbf{1 5 . 1 1}$ & $\mathbf{0 . 3 8}$ & $\mathbf{3 3 . 3 7 \%}$ & $\mathbf{2}$ \\
\hline SBI MAGNUM MID CAP FUND & $\mathbf{4 7 . 9 8}$ & $\mathbf{1 3 . 5 7}$ & $\mathbf{7 1 . 9 4}$ & $\mathbf{1 4 . 9 2}$ & $\mathbf{5 . 3 0}$ & $\mathbf{3 0 . 7 4 \%}$ & $\mathbf{4}$ \\
\hline FRANKLIN INDIA PRIMA FUND & $\mathbf{4 4 . 4 2}$ & $\mathbf{7 . 4 0}$ & $\mathbf{7 8 . 4 1}$ & $\mathbf{6 . 8 1}$ & $\mathbf{7 . 3 0}$ & $\mathbf{2 8 . 8 6 \%}$ & $\mathbf{5}$ \\
\hline
\end{tabular}

Source: Secondary data

Table 2 reveals the return earned by different small \& mid cap funds offered by different Mutual Fund companies during the study period (2012-2016). The average return of FRAKLIN INDIA SMALLER (G) is percent 34.57. The average returns of other funds such as RELIANCE SMALLER CAP (G) MIRAE ASSET 
A Study on the Performace of Equity Mutual Funds (With special reference to equity large cap and ..

EMERGING BLUE CHIP (G) SBI MAGNUM MID CAP (G) and FRANKLIN INDIA PRIMA (G) are 33.37 percent, 32.72 percent, 30.74 percent and 28.86 percent respectively. The return earned by different funds has been ranked. It is observed that the return from FRAKLIN INDIA SMALLER (G) is the highest followed RELIANCE SMALLER CAP FUND, MIRAE ASSET EMERGING BLUE CHIP, SBI MAGNUM MID CAP and FRANKLIN INDIA PRIMA FUND.

TABLE .6 STATSTICAL TOOLS USED FOR EVALUATION OF SMALL \&MID CAP MUTUAL FUNDS

\begin{tabular}{|l|l|l|l|l|l|}
\hline FUND NAME & $\begin{array}{l}\text { Standard } \\
\text { Deviation }\end{array}$ & Beta & Alpha & R.Squared & Sharpe ratio \\
\hline FRAKLIN INDIA SMALLER COMPANIES FUND & $12.073 \%$ & $\mathbf{0 . 8 8}$ & $\mathbf{1 0 . 8 1 \%}$ & $\mathbf{0 . 9 3}$ & $\mathbf{1 . 3 1}$ \\
\hline MIRAE ASSET EMERGING BLUE CHIP FUND & $15.11 \%$ & $\mathbf{1 . 0 3}$ & $\mathbf{1 1 . 6 6 \%}$ & $\mathbf{0 . 9 0}$ & $\mathbf{1 . 2 3}$ \\
\hline RELIANCE SMALLER CAP FUND & $14.77 \%$ & $\mathbf{1 . 0 2}$ & $\mathbf{7 . 9 6 \%}$ & $\mathbf{0 . 9 2}$ & $\mathbf{1 . 0 0}$ \\
\hline SBI MAGNUM MID CAP FUND & $\mathbf{1 5 . 6 5 \%}$ & $\mathbf{1 . 0 2}$ & $\mathbf{6 . 3 7 \%}$ & $\mathbf{0 . 8 3}$ & $\mathbf{0 . 8 4}$ \\
\hline FRANKLIN INDIA PRIMA FUND & $\mathbf{1 3 . 7 5 \%}$ & $\mathbf{0 . 9 6}$ & $\mathbf{5 . 2 5} \%$ & $\mathbf{0 . 9 4}$ & $\mathbf{0 . 8 5}$ \\
\hline
\end{tabular}

Source: Secondary data.

Table.6 reveals the statistical evaluation of small \& mid cap mutual funds. The volatility impact is less for FRAKLIN INDIA SMALLER COMPANIES FUND as its standard deviation is less. The performance of the fund is excellent as revealed by beta, alpha, R-squared and Sharpe ratio. Of these funds considered for the study, FRAKLIN INDIA SMALLER COMPANIES fund has performed well.

\section{Findings}

$>$ There was an increase in NAV of selected five large cap and small\& mid cap mutual fund during the study period (2012-1016).

$>$ Among selected 5 large cap funds SBI BLUE CHIP fund has been ranked first based on various parameters such as fund return, alpha, beta, standard deviation and Sharpe ratio.

> FRANKLIN INDIA SMALLER COMPANIES fund has been ranked first among the five small and mid cap mutual fund. This fund has been analyzed on various parameters like fund return, alpha, beta, standard deviation and sharpe ratio.

\section{Suggestions}

$>$ Investors have to make a self analysis of their needs, risk appetite and expected return so as to develop a prudent investment strategy.

$>$ Due to seasonal fluctuation the investor should think of investment through mutual fund instead of direct investment in equity market.

> Steps have to be taken to improve the level of awareness and financial literacy of retail investors.

\section{Conclusions}

The Indian mutual fund industry is in its growth phase and possesses a tremendous scope for development which is evident for the international growth. From this study it is found that there is an impact of mutual fund flow in the Indian equity markets. Volatility and uncertainty are part and parcel of equity investing. Equity mutual fund investors too cannot remain unscathed when the movement of indices becomes rage bound. As any investor who is interested to have a high return for long term basis the investor can choose large cap mutual fund and if a investor is interested to have moderate return with moderate investment they can opt small and mid cap mutual fund. The investor may monitor the equity fund based on relevant statistical analysis to have better portfolio for his investments.

\section{References}

[1]. Dhanda SK (2012) Performance evaluation of selected open ended mutual funds in India. International Journal of Marketing, Financial Services \& Management Research 1: 29-38.

[2]. Kumar LN, Devi RV (2011) Performance evaluation of private and public sponsored funds in India. International Journal of Research in Commerce and Management 1: 24-35.

[3]. Gohar R, Ahmed S, Niazi U (2011) Performance comparison of mutual funds in Pakistan. African Journal of Business Management 5: 5583-5593

[4]. Prince V, Bacon L (2010) Analyzing mutual fund performance against establishes performance benchmarks: A test of market efficiency. Research in Business and Economics Journal 1: 1-15.

[5]. Debashish SS (2009) Investigating performance of equity- based mutual fund scheme in Indian scenario. KCA Journal of Business Management 2: 1-15.

[6]. GuhaDS (2008) Performance Evaluation of Equity mutual funds in India; An empirical exploration. IIM Calcutta.

[7]. Deb GS, Banerjee A, Chakrabarti BB (2007) Performance of Indian equity mutual funds vis a vis their style benchmarks: An empirical exploration. Journal of Applied Finance, ICFAI.

[8]. PanwarSharad, Madhumathi RM (2006) Characteristics and performance evaluation of selected mutual funds in India. Institute of capital Market 9th Capital market Conference paper. 
A Study on the Performace of Equity Mutual Funds (With special reference to equity large cap and ..

[9]. Noulas G and Athanasius (2005) Performance of mutual funds. Managerial Finance 31:101-112.

[10]. Rao NS, Ravindram M (2002) Performance of Indian mutual funds. Proceedings of 15th Australasian Finance and Banking Conference held in Sydney (Australia) on 16-18 December 2002.

[11]. Sharpe WF (1966) Mutual Fund Performance. Journal of Business 39: 119-138.

[12]. Treynor JL (1965) How to rate management of investment funds? Harvard Business Review 43(1): 63-75.

[13]. Jensen MC (1968) The performance of mutual funds in the period 1945-1964. Journal of Finance 23(2): 389-416.

[14]. Fama EF (1972) Components of Investment Performance. Journal of Finance 27: 551 - 567.

[15]. https://www.researchgate.net/publication/267367938_AN_EMPIRICAL_STUDY_ON_INDIAN_MUTUAL_FUNDS_EQUITY_D IVERSIFIED_GROWTH_SCHEMES_AND_THEIR_PERFORMANCE_EVALUATION 